\title{
Pengaruh Takaran Pupuk Kandang Babi dan Jarak Tanam Terhadap Pertumbuhan dan Hasil Wortel (Daucus carota, L.)
}

Imelda Yuniwati Berek ${ }^{\mathrm{a}}$

${ }^{a}$ Fakultas Pertanian, Universitas Timor, Kefamenanu, TTU - NTT, 85613, Indonesia

\section{Article Info}

\section{Article history:}

Received 14 September 2015

Received in revised form 14 Januari 2016

Accepted 15 Februari 2016

\section{Keywords:}

Jarak tanam

Pupuk Kandang Babi

Takaran

\begin{abstract}
Abstrak
Penelitian ini bertujuan untuk mengetahui pengaruh takaran pupuk kandang babi dan jarak tanam terhadap pertumbuhan dan hasil wortel serta mengetahui takaran pupuk kandang dan jarak tanam yang tepat untuk pertumbuhan dan hasil wortel yang optimum. Rancangan yang digunakan adalah Rancangan Acak Kelompok (RAK) faktorial 3 x 3 yang diulang tiga kali. Faktor pertama adalah takaran pupuk kandang babi yang terdiri dari tiga aras yaitu $15 \mathrm{t} \mathrm{ha}^{-1}, 25 \mathrm{t} \mathrm{ha}^{-1}$ dan $35 \mathrm{t} \mathrm{ha}^{-1}$. Faktor kedua adalah jarak tanam yang terdiri dari tiga aras yaitu $10 \mathrm{~cm} \times 15 \mathrm{~cm}, 10 \mathrm{~cm}$ x $20 \mathrm{~cm}$ dan $15 \mathrm{~cm} \times 15 \mathrm{~cm}$. Hasil penelitian menunjukkan tidak terjadi pengaruh interaksi antara takaran pupuk kandang babi dan jarak tanam terhadap semua parameter. Takaran pupuk kandang babi berpengaruh nyata pada parameter kadar lengas 50 HST dan panjang umbi, sedangkan jarak tanam tidak berpengaruh nyata terhadap semua parameter. Pemberian pupuk kandang babi dengan takaran $35 \mathrm{t} \mathrm{ha}^{-1}$ memberikan hasil tertinggi yakni $30,95 \mathrm{t} \mathrm{ha}^{-1}$, sedangkan jarak tanam $15 \mathrm{~cm} \times 15 \mathrm{~cm}$ memberikan hasil wortel tertinggi yakni $30,85 \mathrm{t} \mathrm{ha}^{-1}$. ()2016 dipublikasikan oleh Savana Cendana.
\end{abstract}

\section{Pendahuluan}

Wortel (Daucus carota, L.) bukan tanaman asli Indonesia, melainkan berasal dari luar negeri yang beriklim sedang. Menurut sejarahnya, tanaman wortel berasal dari Asia Timur dan Asia Tengah. Tanaman ini ditemukan tumbuh liar sekitar 6500 tahun yang lalu. Pada awalnya budidaya wortel terjad di daerah sekitar laut tengah. Lambat laun budidaya wortel menyebar luas ke daerah Asia, Eropa, Afrika dan seluruh dunia yang telah terkenal dengan daerah pertaniannya. Tidak hanya di negara beriklim sedang saja, penanaman wortel menyebar juga ke negara-negara beriklim panas termasuk di Indonesia Walaupun pada awalnya hanya ditanam di daerah Lembang dan Cipanas (Jawa Barat). Namun, dalam perkembangannya menyebar ke daerah-daerah sentra sayuran di Jawa dan luar Jawa (Cahyono, 2002).

Produktivitas wortel di provinsi Nusa Tenggara Timur (NTT) masih tergolong sangat rendah (Tabel 1.) jika dibandingkan dengan produktivitas wortel nasional maupun beberapa negara lain. Produksi wortel di Kabupaten Timor Tengah Utara (TTU) pada tahun 2010 sebanyak 40 ton mengalami penurunan bila dibanding dengan tahun 2009 sebanyak 95 ton.

Berdasarkan data Direktorat Jenderal Hortikultura (2013), pada tahun 2012 produksi wortel di Indonesia sebesar 465,53 ribu ton. Data FAO (1995) cit. Hadirochmat (2006) menunjukkan bahwa negara produsen wortel terkemuka adalah Cina, Amerika Serikat dan Federasi Rusia yang berturut-turu menghasilkan $17 \%, 9 \%$ dan $8 \%$ pasokan wortel dunia dari luas areal 6.660 .000 ha, produktivitas yang paling tinggi adalah Belanda yaitu $56,2 \mathrm{t} \mathrm{ha}^{-1}$, berikutnya Inggris $46 \mathrm{t} \mathrm{ha}^{-1}$, Italia 44,3 $\mathrm{tha}^{-1}$ dan Kanada $40,7 \mathrm{t} \mathrm{ha}^{-1}$.

Tabel 1. Produktivitas Wortel Propinsi Nusa Tenggara Timur

\begin{tabular}{cccc}
\hline Tahun & $\begin{array}{c}\text { Luas panen } \\
(\text { ha })\end{array}$ & Produksi (t) & $\begin{array}{c}\text { Produktivitas } \\
\left(\mathrm{t} \mathrm{ha}^{-1}\right)\end{array}$ \\
\hline 2009 & 279 & 2.410 & 8,64 \\
2010 & 406 & 1.235 & 3,04 \\
2011 & 274 & 1.613 & 5,86 \\
2012 & 267 & 863 & 3,23 \\
2013 & 276 & 1.106 & 4,01 \\
\hline
\end{tabular}

Sumber : BPS NTT (2014)

Peningkatan hasil tanaman wortel dapat dicapai melalui perbaikan teknologi budidaya tanaman, salah satunya adalah pemberian pupuk untuk peningkatan produktivitas lahan dan tanaman. Menurut Santoso (1994) pemupukan merupakan syarat mutlak dalam membudidayakan suatu tanaman, pemupukan bertujuan untuk menggantikan unsur hara yang hilang karena proses pencucian dan pengangkutan bersama limbah pertanian.

Dalam kegiatan pemupukan tanah dan tanaman harus mempertimbangkan faktor-faktor antara lain tanaman yang akan dipupuk, jenis pupuk yang digunakan, dosis pupuk, cara aplikasi pupuk dan waktu pemupukan. Menururt Nurhayati (2000), pemberian pupuk kandang mampu meningkatkan kesuburan tanah, daya menahan air, serta kapasitas tukar kation. Struktur tanah yang baik menjadikan perakaran berkembang dengan baik sehingga semakin luas bidang serapan terhadap unsur hara. Kelancaran proses penyerapan unsur hara oleh tanaman terutama difusi tergantung dari persediaan air tanah yang berhubungan erat dengan kapasitas menahan air oleh tanah.

Selain pemberian pupuk kandang yang tepat, peningkatan hasil wortel juga dapat dicapai melalui pengaturan jarak tanam. Menurut Williams dan Yoseph (1970) cit. Indrayanti (2010), pengaturan jarak tanam sangat berpengaruh terhadap pertumbuhan dan hasil tanaman. Hal ini akan berpengaruh pada luas daun, berat kering tanaman, sistem perakaran, banyaknya sinar matahari yang diterima dan banyaknya unsur hara yang diserap dari dalam tanah. Penggunaan jarak tanam yang tepat akan menaikkan hasil, tetapi penggunaan jarak tanam yang kurang tepat akan menurunkan hasil.

Berdasarkan uraian di atas maka dapat diketahui bahwa penggunaan takaran pupuk kandang dan jarak tanam yang tepat dapat meningkatkan pertumbuhan dan hasil tanaman. Permasalahannya adalah belum diketahuinya pengaruh takaran pupuk kandang babi dan jarak tanam terhadap pertumbuhan dan hasil tanaman wortel. Penelitian ini bertujuan untuk mengetahui pengaruh takaran pupuk kandang babi dan jarak tanam terhadap pertumbuhan dan hasil wortel serta mengetahui takaran pupuk kandang dan jarak tanam yang tepat untuk pertumbuhan dan hasil wortel yang optimum.

\section{Metode}

\subsection{Waktu dan Tempat}

Penelitian dilaksanakan pada bulan Mei sampai Agustus di kebun percobaan Fakultas Pertanian, Universitas Timor Kelurahan Sasi, Kecamatan Kota Kefamenanu, Kabupaten TTU. Topografi berbukit-bukit dengan ketinggian $\pm 400 \mathrm{~m} \mathrm{dpl}$, curah hujan $900-1.500 \mathrm{~mm}$ per tahun, suhu udara berkisar antara $27^{\circ} \mathrm{C}$ (BPS, 2007).

\subsection{Rancangan Percobaan}

Penelitian mengunakan Rancangan Acak Kelompok (RAK) faktorial 3 x 3 yang diulang tiga kali. Faktor pertama adalah takaran pupuk kandang babi $(\mathrm{T})$ yang terdiri dari tiga aras yaitu $15 \mathrm{t} \mathrm{ha}^{-1}\left(\mathrm{t}_{1}\right), 25 \mathrm{t} \mathrm{ha}^{-1}\left(\mathrm{t}_{2}\right)$ dan $35 \mathrm{tha}^{-1}\left(\mathrm{t}_{3}\right)$ Faktor kedua adalah jarak tanam $(\mathrm{J})$ yang terdiri dari tiga aras yaitu $10 \mathrm{~cm} \times 15$ $\mathrm{cm}\left(\mathrm{j}_{1}\right), 10 \mathrm{~cm}$ x $20 \mathrm{~cm}\left(\mathrm{j}_{2}\right)$ dan $15 \mathrm{~cm}$ x $15 \mathrm{~cm}\left(\mathrm{j}_{3}\right)$. Kombinasi perlakuannya adalah $\mathrm{t}_{1} \mathrm{j}_{1}, \mathrm{t}_{1} \mathrm{j}_{2}, \mathrm{t}_{1} \mathrm{j}_{3}, \mathrm{t}_{2} \mathrm{j}_{1}, \mathrm{t}_{2} \mathrm{j}_{2}, \mathrm{t}_{2} \mathrm{j}_{3}, \mathrm{t}_{3} \mathrm{j}_{1}, \mathrm{t}_{3} \mathrm{j}_{2}$ dan $\mathrm{t}_{3} \mathrm{j}_{3}$

\subsection{Pelaksanaan Penelitian}

a. Persiapan Benih

Benih wortel yang digunakan dalam penelitian ini adalah wortel varietas New Kuroda yang dibeli dari toko sarana produksi pertanian. Benih yang disiapkan untuk penelitian ini sebanyak $75 \mathrm{~g}$

b. Pengolahan Tanah

Tanah terlebih dahulu dibersihkan dari gulma dan serta vegetasi lainnya untuk selanjutnya dilakukan pengolahan. Pengolahan tanah dilakukan dengan menggunakan cangkul, kemudian dilanjutkan dengan penggemburan tanah. Lahan yang digunakan berukuran panjang 13,2 $\mathrm{m}$ dan lebar 6,2 $\mathrm{m}$ dengan luas $81,8 \mathrm{~m}^{2}$. Lahan dibagi dalam tiga blok dan pada masing-masing blok dibuat sembilan petak percobaan berbentuk bedeng dengan ukuran panjang 1,4 $\mathrm{m}$ dan lebar $0,8 \mathrm{~m}$ dengan luas $1,12 \mathrm{~m}^{2}$, sehingga secara keseluruhan terdapat 27 petak Jarak antara petak $0,5 \mathrm{~m}$ dan jarak antara blok $1 \mathrm{~m}$. Pada setiap blok, petak dan tanaman sampel diberikan label menggunakan tiang bambu dan seng.

c. Pemupukan

Pupuk yang digunakan dalam penelitian ini adalah pupuk kandang yang berasal dari ternak babi yang telah mengalami pengomposan. Pemberian pupuk kandang babi dilakukan dengan cara pembenaman dalam tanah bersamaan dengan pengolahan tanah dengan takaran sesuai perlakuan. Pada sembilan petak percobaan diberikan dengan dosis $15 \mathrm{t} \mathrm{ha}^{-1}$ atau $1,68 \mathrm{~kg}$ per petak, sembilan petak percobaan diberikan dengan dosis $25 \mathrm{t} \mathrm{ha}^{-1}$ atau $2,8 \mathrm{~kg}$ per petak dan sembilan petak percobaan diberikan dengan dosis $35 \mathrm{t} \mathrm{ha}^{-1}$ atau 3,92 $\mathrm{kg}$ per petak. Total kebutuhan pupuk sebanyak $75,6 \mathrm{~kg}$.

d. Penanaman

Penanaman dilakukan pada sore hari dengan cara tabur benih langsung. Sebelum benih ditabur, terlebih dahulu melakukan penyiraman pada petak yang ada, lalu membuat larikan sesuai jarak antar baris dengan dalam $+2 \mathrm{~cm}$, selanjutnya melakukan penaburan benih dalam larikan kemudian ditutup dengan tanah. Selanjutnya akan dilakukan penjarangan agar jarak tanam sesuai dengan perlakuan.

e. Penjarangan

Penjarangan dilakukan sekali saat tanaman berumur 20 HST, penjarangan dilakukan dengan mencabut tanaman wortel yang tumbuh di dalam setiap larikan dan meninggalkan satu tanaman sesuai dengan jarak tanam yang ditentukan. Sembilan petak menggunakan jarak tanam $10 \mathrm{~cm}$ x $15 \mathrm{~cm}$ dengan jumlah tanaman setiap petak 72 tanaman, sembilan petak menggunakan jarak tanam $10 \mathrm{~cm} \times 20 \mathrm{~cm}$ dengan jumlah tanaman setiap petak 56 tanaman dan 
sembilan petak menggunakan jarak tanam $15 \mathrm{~cm}$ x $15 \mathrm{~cm}$ dengan jumlah tanaman setiap petak 45 tanaman. Jumlah keseluruhan 1557 tanaman.

f. Pemeliharaan

Pemeliharaan meliputi penyiraman, penyiangan serta pengendalian hama dan penyakit tanaman (HPT). Penyiraman dilakukan dua kali sehari, yaitu pagi dan sore menggunakan gembor yang volume airnya diberikan secara merata pada setiap bedengan sampai selesai penelitian. Penyiangan dilakukan dengan menggunakan tajak untuk membersihkan tanaman pengganggu sekaligus melakukan penggemburan. Pengendalian HPT tidak dilakukan karena tanaman tidak mengalami serangan hama dan penyakit.

g. Panen

Bagian yang dipanen dari tanaman wortel adalah umbi. Tanaman wortel dipanen saat umur 110 HST dengan ciri-ciri daunnya sudah menguning atau kering dengan cara mencabut per tanaman.

\subsection{Parameter Pengamatan}

a. Suhu Tanah $\left({ }^{\circ} \mathrm{C}\right)$

Pengukuran suhu tanah dilakukan empat kali selama penelitian yakni -1 HST, 25 HST, 50 HST dan 75 HST, menggunakan thermometer suhu tanah, dengan cara ditancapkan pada kedalaman tanah $5 \mathrm{~cm}$ selama 3 menit pada tiga titik untuk setiap petak. Pengukuran dilakukan pada siang hari pukul 12.0014.00 WITA.

b. Kadar Lengas Tanah (\%)

Sampel tanah diambil dengan cara menggali sedalam $5 \mathrm{~cm}$ pada tiga titik untuk setiap petak. Sampel tanah yang sudah diambil berbentuk gumpalan +2 $\mathrm{cm}$, kemudian disimpan dalam wadah plastik yang ditandai dengan label, kemudian ditimbang untuk mengetahui berat basah, selanjutnya dioven selama 48 jam pada suhu $105^{\circ} \mathrm{C}$, kemudian ditimbang untuk mengetahui berat kering. Pengukuran dilakukan sebanyak empat kali selama penelitian yakni -1 HST, 25 HST, 50 HST dan 75 HST. Kadar lengas tanah dihitung dengan rumus (Setiawan, 2012):

$$
\begin{aligned}
& \mathrm{KL}=\frac{\mathrm{BB}-\mathrm{BK}}{\mathrm{BK}} \times 100 \% \\
\text { Keterangan } & : \\
\text { KL } & : \text { Kadar Lengas Tanah }(\%) \\
\mathrm{BB} & : \text { Berat Basah }(\mathrm{g}) \\
\mathrm{BK} & : \text { Berat Kering }(\mathrm{g})
\end{aligned}
$$

\section{c. Berat Volume Tanah $\left(\mathrm{g} / \mathrm{cm}^{3}\right)$}

Sampel tanah kering dari pengukuran kadar lengas tanah kemudian diikat dengan tali raffia sepanjang $10 \mathrm{~cm}$ dan dicelupkan ke dalam cairan lilin dalam wadah alumunium yang dipanaskan dengan lampu spritus. Gumpalan tanah yang telah dilapisi lilin dicelupkan ke dalam gelas ukur berisi air setinggi $40 \mathrm{ml}$ Kenaikan volume air dihitung sebagai volume tanah. Berat volume tanah dihitung dengan rumus (Hardjowigeno, 2012):

$$
\mathrm{BV}=\frac{\mathrm{B}}{\mathrm{V}}
$$

$\begin{array}{cl}\text { Keterangan } & : \\ \text { BV } & \text { : Berat Volume Tanah }\left(\mathrm{g} / \mathrm{cm}^{3}\right) \\ \text { B } & \text { : Berat Tanah Kering }(\mathrm{g}) \\ \text { V } & : \text { Volume Tanah }\left(\mathrm{cm}^{3}\right)\end{array}$

d. Tinggi Tanaman (cm)

Tinggi tanaman diukur dari pangkal batang sampai ujung daun paling tinggi, pengukuran menggunakan pengaris centimeter. Pengukuran dilakukan pada tujuh tanaman sampel saat berumur 25 HST, 50 HST dan 75 HST.

e. Luas Daun $\left(\mathrm{cm}^{2}\right)$

Pengukuran luas daun dilakukan pada saat tanaman wortel di panen Pengukuran luas daun dilakukan menggunakan metode fotografi dengan cara mengambil semua daun pada tujuh tanaman sampel pada tiap petak, kemudian daun dipotret menggunakan kamera digital. Luas area daun kemudian dihitung menggunakan program Image J versi 1,410 .

f. Panjang Umbi $(\mathrm{cm})$

Panjang umbi diukur dari pangkal sampai ujung umbi yang dihasilkan tujuh tanaman sampel, pengukuran menggunakan pengaris centimeter.

g. Diameter Umbi (mm)

Diameter umbi diukur dengan cara menjepit jangka sorong pada bagian pangkal, tengah dan ujung umbi yang dihasilkan tujuh tanaman sampel kemudian dirata-ratakan.

\section{h. Berat Umbi Per Tanaman (g)}

Berat umbi per tanaman diukur dengan cara menimbang umbi wortel dari tujuh tanaman sampel menggunakan timbangan duduk.

i. Berat Umbi Per Petak ( $\left.\mathrm{t} \mathrm{ha}^{-1}\right)$

Berat umbi per petak diukur dengan cara menimbang semua umbi wortel setiap petak menggunakan timbangan duduk kemudian dikonversi ke $\mathrm{t} / \mathrm{ha}$.

j. Berat Segar Berangkasan ( $\left.\mathrm{t} \mathrm{ha}^{-1}\right)$

Berat segar berangkasan diukur dengan cara menimbang berangkasan semua tanaman dalam setiap petak setelah dipanen kemudian dikonversikan ke satuan $\mathrm{tha}^{-1}$

\section{k. Berat Kering Berangkasan $\left(\mathrm{t} \mathrm{ha}^{-1}\right)$}

Berat kering berangkasan diukur dengan cara menimbang berangkasan semua tanaman dalam setiap petak yang telah dipanen dan dijemur selama empat hari kemudian dikonversikan ke satuan $\mathrm{t} \mathrm{ha}^{-1}$.

1. Indeks Panen (\%)

Indeks panen dihitung dengan cara membandingkan berat bagian tanaman yang bernilai ekonomis dengan berat bagian seluruh tanaman kemudian dikonversikan ke satuan \%. Indeks panen dihitung dengan rumus;

$$
\begin{array}{cl} 
& \multicolumn{1}{c}{\mathrm{IP}=\frac{\mathrm{A}}{\mathrm{A}+\mathrm{B}} \times 100 \%} \\
\text { Keterangan } & : \\
\text { IP } & : \text { Indeks Panen }(\%) \\
\text { A } & : \text { Berat Umbi Per Petak (t/ha) } \\
\text { B } & : \text { Berat Segar Brangkasan (t/ha) }
\end{array}
$$

\subsection{Analisis Data}

Data hasil pengamatan kemudian dianalisis dengan menggunakan sidik ragam (Anova) Rancangan Acak Kelompok (RAK). Rata-rata perlakuan selanjutnya diuji lanjut dengan menggunakan Duncan Multiple Range Test (DMRT) dengan tingkat signifikasi 5\% sesuai petunjuk Gomez dan Gomez

\begin{tabular}{|c|c|c|c|c|c|}
\hline \multirow{2}{*}{$\begin{array}{c}\text { Waktu } \\
\text { Pengamatan }\end{array}$} & \multirow{2}{*}{$\begin{array}{l}\text { Takaran } \\
\text { Pupuk }\end{array}$} & \multicolumn{3}{|c|}{ Jarak Tanam } & \multirow[t]{2}{*}{ Rerata } \\
\hline & & $10 \times 15$ & $10 \times 20$ & $15 \times 15$ & \\
\hline \multirow{4}{*}{$-1 \mathrm{HST}$} & $15 \mathrm{t} \mathrm{ha}^{-1}$ & 28,01 & 28,12 & 28,04 & 28,06 a \\
\hline & $25 \mathrm{t} \mathrm{ha}^{-1}$ & 27,77 & 28,14 & 28,07 & 27,99 a \\
\hline & $35 \mathrm{t} \mathrm{ha}^{-1}$ & 28,23 & 28,07 & 28,01 & $28,10 \mathrm{a}$ \\
\hline & Rerata & 28,00 & 28,11 & 28,04 & $(-)$ \\
\hline \multirow{4}{*}{$25 \mathrm{HST}$} & $15 \mathrm{t} \mathrm{ha}^{-1}$ & $28,11 \mathrm{a}$ & $28,01 \mathrm{a}$ & $27,31 \mathrm{a}$ & $27,81 \mathrm{a}$ \\
\hline & $25 \mathrm{t} \mathrm{ha}^{-1}$ & $27,37 \mathrm{a}$ & $27,68 \mathrm{a}$ & $27,42 \mathrm{a}$ & $27,49 \mathrm{a}$ \\
\hline & $35 \mathrm{t} \mathrm{ha}^{-1}$ & $28,07 \mathrm{a}$ & $28,28 \mathrm{a}$ & $28,10 \mathrm{a}$ & $28,15 \mathrm{a}$ \\
\hline & Rerata & $27,85 \mathrm{a}$ & $27,99 \mathrm{a}$ & $27,61 \mathrm{a}$ & $(-)$ \\
\hline \multirow{4}{*}{$50 \mathrm{HST}$} & $15 \mathrm{t} \mathrm{ha}^{-1}$ & $27,83 \mathrm{a}$ & $27,61 \mathrm{a}$ & $28,02 \mathrm{a}$ & $27,82 \mathrm{a}$ \\
\hline & $25 \mathrm{t} \mathrm{ha}^{-1}$ & $27,67 \mathrm{a}$ & $27,69 \mathrm{a}$ & $27,63 \mathrm{a}$ & $27,66 \mathrm{a}$ \\
\hline & $35 \mathrm{t} \mathrm{ha}^{-1}$ & $27,50 \mathrm{a}$ & $27,48 \mathrm{a}$ & $27,43 \mathrm{a}$ & $27,47 \mathrm{a}$ \\
\hline & Rerata & $27,67 \mathrm{a}$ & $27,59 \mathrm{a}$ & $27,70 \mathrm{a}$ & $(-)$ \\
\hline \multirow{4}{*}{75 HST } & $15 \mathrm{t} \mathrm{ha}^{-1}$ & $27,60 \mathrm{a}$ & $27,49 \mathrm{a}$ & $27,00 \mathrm{a}$ & $27,36 \mathrm{a}$ \\
\hline & $25 \mathrm{t} \mathrm{ha}^{-1}$ & $26,93 \mathrm{a}$ & $27,69 \mathrm{a}$ & $27,43 \mathrm{a}$ & $27,35 \mathrm{a}$ \\
\hline & $35 \mathrm{t} \mathrm{ha}^{-1}$ & $26,67 \mathrm{a}$ & $26,71 \mathrm{a}$ & $27,27 \mathrm{a}$ & $26,88 \mathrm{a}$ \\
\hline & Rerata & $27,07 \mathrm{a}$ & $27,30 \mathrm{a}$ & $27,23 \mathrm{a}$ & $(-)$ \\
\hline Keterangan : & $\begin{array}{l}\text { Angka pad } \\
\text { tidak berbe } \\
\text { interaksi an }\end{array}$ & faktor & yang dii & $\begin{array}{l}\text { lengan hu } \\
5 \% \text {. ( - ) }\end{array}$ & $\begin{array}{l}\text { yang sama } \\
\text { dak terjadi }\end{array}$ \\
\hline
\end{tabular}
(1995). Analisis data menggunakan program SAS 9,1.

\section{Hasil dan Pembahasan}

\subsection{Suhu Tanah}

Suhu tanah selama penelitian dari pengamatan awal hingga pengamatan terakhir dengan kisaran suhu antara 26,67 - 28,28 ${ }^{\circ} \mathrm{C}$. Hasil sidik ragam (Anova) menunjukkan tidak terjadi interaksi antara takaran pupuk kandang dan jarak tanam disetiap waktu pengamatan.

Tabel 2. Suhu Tanah $\left({ }^{\circ} \mathrm{C}\right)$

Takaran pupuk kandang tidak berpengaruh nyata pada suhu tanah semua waktu pengamatan tetapi data pada Tabel 2. menunjukkan bahwa pada waktu pengamatan -1 HST dan 25 HST suhu tanah tertinggi terdapat pada petak yang diberikan pupuk dengan takaran $35 \mathrm{t} \mathrm{ha}^{-1}$ dan suhu tanah terendah terdapat pada petak yang diberikan pupuk kandang babi dengan takaran $15 \mathrm{t} \mathrm{ha}^{-1}$. Namun pada pengamatan 50 HST dan 75 HST suhu tertinggi terdapat pada petak yang diberikan pupuk dengan takaran $15 \mathrm{t} \mathrm{ha}^{-1}$ dan terendah terdapat pada takaran pupuk kandang $35 \mathrm{t} \mathrm{ha}^{-1}$. Jarak tanam juga tidak berpengaruh nyata terhadap suhu tanah setiap waktu pengamatan, pada pengamatan 25 HST suhu tanah tertinggi terjadi pada petak yang ditanami wortel dengan jarak $10 \mathrm{~cm}$ x $20 \mathrm{~cm}$ dan suhu tanah terendah terdapat pada petak yang ditanami wortel dengan jarak $15 \mathrm{~cm} \times 15 \mathrm{~cm}$. Selanjutnya pada pengamatan 50 HST suhu tanah tertinggi terjadi pada petak yang ditanami wortel dengan jarak $15 \mathrm{~cm}$ x $15 \mathrm{~cm}$ dan suhu tanah terendah terdapat pada petak yang ditanami wortel dengan jarak $10 \mathrm{~cm} \mathrm{x}$ $20 \mathrm{~cm}$. Pada pengamatan 75 HST, suhu tanah tertinggi terjadi pada petak yang ditanami wortel dengan jarak $10 \mathrm{~cm}$ x $50 \mathrm{~cm}$ dan suhu tanah terendah terdapat pada petak yang ditanami wortel dengan jarak $10 \mathrm{~cm}$ x $20 \mathrm{~cm}$.

\subsection{Kadar Lengas Tanah}

Hasil sidik ragam (Anova) menunjukkan tidak terjadi interaksi antara takaran pupuk kandang babi dan jarak tanam pada setiap waktu pengamatan. Takaran pupuk kandang babi maupun jarak tanam juga tidak memberikan pengaruh utama yang nyata terhadap kadar lengas tanah setiap waktu pengamatan.

Data Tabel 3. menunjukkan bahwa pada pengamatan -1 HST dan 75 HST, kadar lengas tanah tertinggi terdapat pada petak yang diberikan pupuk kandang babi dengan takaran $35 \mathrm{t} \mathrm{ha}^{-1}$ sedangkan kadar lengas terendah terdapat pada petak yang diberikan pupuk kandang babi dengan takaran $15 \mathrm{t} \mathrm{ha}^{-1}$. Saat pengamatan $25 \mathrm{HST}$ dan $50 \mathrm{HST}$, kadar lengas tanah tertinggi terdapat pada 
petak yang diberikan pupuk kandang babi dengan takaran $15 \mathrm{t} \mathrm{ha}^{-1}$ sedangkan kadar lengas terendah terdapat pada petak yang diberikan pupuk kandang babi dengan takaran $25 \mathrm{t} \mathrm{ha}^{-1}$. Pada pengamatan $25 \mathrm{HST}$ dan $75 \mathrm{HST}$, kadar lengas tanah tertinggi terjadi pada petak yang ditanami wortel dengan jarak $15 \mathrm{~cm}$ x 15 $\mathrm{cm}$ dan kadar lengas tanah terendah terdapat pada petak yang ditanami wortel dengan jarak $10 \mathrm{~cm} \times 15 \mathrm{~cm}$. Sedangkan pada pengamatan 50 HST kadar lengas tanah tertinggi terjadi pada petak yang ditanami wortel dengan jarak 10 $\mathrm{cm}$ x $15 \mathrm{~cm}$ dan kadar lengas tanah terendah terdapat pada petak yang ditanami wortel dengan jarak $10 \mathrm{~cm} \times 20 \mathrm{~cm}$.

Tabel 3. Kadar Lengas Tanah (\%)

\begin{tabular}{|c|c|c|c|c|c|}
\hline \multirow{2}{*}{$\begin{array}{c}\text { Waktu } \\
\text { Pengamatan }\end{array}$} & \multirow{2}{*}{$\begin{array}{c}\text { Takaran } \\
\text { Pupuk }\end{array}$} & \multicolumn{3}{|c|}{ Jarak Tanam } & \multirow{2}{*}{ Rerata } \\
\hline & & $10 \times 15$ & $10 \times 20$ & $15 \times 15$ & \\
\hline \multirow{4}{*}{-1 HST } & $15 \mathrm{tha}^{-1}$ & 38,56 & 36,02 & 40,14 & $38,24 \mathrm{a}$ \\
\hline & $25 \mathrm{tha}^{-1}$ & 41,03 & 35,44 & 39,31 & $38,59 \mathrm{a}$ \\
\hline & $35 \mathrm{t} \mathrm{ha}^{-1}$ & 41,96 & 44,49 & 41,20 & $42,55 \mathrm{a}$ \\
\hline & Rerata & 40,51 & 38,65 & 40,22 & $(-)$ \\
\hline \multirow{4}{*}{$25 \mathrm{HST}$} & $15 \mathrm{t} \mathrm{ha}^{-1}$ & $36,99 \mathrm{a}$ & $37,55 \mathrm{a}$ & $40,78 \mathrm{a}$ & $38,44 \mathrm{a}$ \\
\hline & $25 \mathrm{t} \mathrm{ha}^{-1}$ & 28,74 a & $32,96 \mathrm{a}$ & $38,70 \mathrm{a}$ & $33,47 \mathrm{a}$ \\
\hline & $35 \mathrm{t} \mathrm{ha}^{-1}$ & $37,02 \mathrm{a}$ & $38,81 \mathrm{a}$ & $34,67 \mathrm{a}$ & $36,83 \mathrm{a}$ \\
\hline & Rerata & $34,25 \mathrm{a}$ & $36,44 \mathrm{a}$ & $38,05 \mathrm{a}$ & $(-)$ \\
\hline \multirow{4}{*}{$50 \mathrm{HST}$} & $15 \mathrm{t} \mathrm{ha}^{-1}$ & $35,10 \mathrm{a}$ & $32,63 \mathrm{a}$ & $34,47 \mathrm{a}$ & $34,07 \mathrm{a}$ \\
\hline & $25 \mathrm{t} \mathrm{ha}^{-1}$ & $30,50 \mathrm{a}$ & $30,57 \mathrm{a}$ & 29,19 a & $30,09 \mathrm{~b}$ \\
\hline & $35 \mathrm{t} \mathrm{ha}^{-1}$ & $31,97 \mathrm{a}$ & $30,60 \mathrm{a}$ & $33,56 \mathrm{a}$ & $32,05 \mathrm{ab}$ \\
\hline & Rerata & $32,52 \mathrm{a}$ & $31,27 \mathrm{a}$ & $32,41 \mathrm{a}$ & $(-)$ \\
\hline \multirow{4}{*}{75 HST } & $15 \mathrm{t} \mathrm{ha}^{-1}$ & $30,57 \mathrm{~b}$ & $30,67 \mathrm{~b}$ & $31,19 \mathrm{ab}$ & $30,81 \mathrm{a}$ \\
\hline & $25 \mathrm{t} \mathrm{ha}^{-1}$ & $29,77 \mathrm{~b}$ & $31,50 \mathrm{ab}$ & $31,33 \mathrm{ab}$ & $30,86 \mathrm{a}$ \\
\hline & $35 \mathrm{t} \mathrm{ha}^{-1}$ & $31,19 \mathrm{ab}$ & $31,11 \mathrm{ab}$ & $34,56 \mathrm{a}$ & $32,29 \mathrm{a}$ \\
\hline & Rerata & $30,51 \mathrm{a}$ & $31,09 \mathrm{a}$ & $32,36 \mathrm{a}$ & $(-)$ \\
\hline Keterangan : & $\begin{array}{l}\text { Angka pa } \\
\text { tidak berb } \\
\text { interaksi a }\end{array}$ & $\begin{array}{l}\text { baris dan } \\
\text { nyata me } \\
\text { if faktor }\end{array}$ & $\mathrm{m}$ yang d & dengan $\mathrm{h}$ & \\
\hline
\end{tabular}

\subsection{Berat Volume Tanah}

Berat volume tanah selama penelitian berkisar antara 1,49-1,58. Hasil sidik ragam (Anova) menunjukkan tidak terjadi interaksi antara takaran pupuk kandang babi dan jarak tanam terhadap berat volume tanah setiap waktu pengamatan. Takaran pupuk kandang babi maupun jarak tanam juga tidak memberikan pengaruh utama yang nyata terhadap berat volume tanah setiap waktu pengamatan.

Data pada Tabel 4. menunjukkan bahwa pada waktu pengamatan -1 HST berat volume tanah tertinggi terdapat pada petak yang diberikan pupuk kandang babi dengan takaran $25 \mathrm{t} \mathrm{ha}^{-1}$ sedangkan berat volume tanah terendah terdapat pada petak yang diberikan pupuk kandang babi dengan takaran $15 \mathrm{t} \mathrm{ha}^{-1}$. Pada pengamatan selanjutnya, petak yang diberikan pupuk kandang babi dengan takaran $35 \mathrm{t} \mathrm{ha}^{-1}$ selalu memiliki berat volume tanah yang paling tinggi. Petak yang ditanami wortel dengan jarak $10 \mathrm{~cm} \times 15 \mathrm{~cm}$ selalu memiliki berat volume tanah yang paling tingggi setiap kali pengamatan.

Tabel 4. Berat Volume Tanah $\left(\mathrm{g} / \mathrm{cm}^{3}\right)$

\begin{tabular}{|c|c|c|c|c|c|}
\hline \multirow{2}{*}{$\begin{array}{c}\text { Waktu } \\
\text { Pengamatan }\end{array}$} & \multirow{2}{*}{$\begin{array}{c}\text { Takaran } \\
\text { Pupuk }\end{array}$} & \multicolumn{3}{|c|}{ Jarak Tanam } & \multirow{2}{*}{ Rerata } \\
\hline & & $10 \times 15$ & $10 \times 20$ & $15 \times 15$ & \\
\hline \multirow{4}{*}{$-1 \mathrm{HST}$} & $15 \mathrm{tha}^{-1}$ & 1,50 & 1,52 & 1,54 & $1,52 \mathrm{a}$ \\
\hline & $25 \mathrm{tha}^{-1}$ & 1,56 & 1,56 & 1,53 & $1,55 \mathrm{a}$ \\
\hline & $35 \mathrm{tha}^{-1}$ & 1,56 & 1,56 & 1,51 & $1,54 \mathrm{a}$ \\
\hline & Rerata & 1,54 & 1,55 & 1,53 & $(-)$ \\
\hline \multirow{4}{*}{$25 \mathrm{HST}$} & $15 \mathrm{t} \mathrm{ha}^{-1}$ & $1,54 \mathrm{ab}$ & $1,55 \mathrm{ab}$ & $1,50 \mathrm{~b}$ & $1,53 \mathrm{a}$ \\
\hline & $25 \mathrm{tha}^{-1}$ & $1,54 \mathrm{ab}$ & $1,55 \mathrm{ab}$ & $1,54 \mathrm{ab}$ & $1,54 \mathrm{a}$ \\
\hline & $35 \mathrm{tha}^{-1}$ & $1,55 \mathrm{ab}$ & $1,54 \mathrm{ab}$ & $1,57 \mathrm{a}$ & $1,56 \mathrm{a}$ \\
\hline & Rerata & $1,55 \mathrm{a}$ & $1,55 \mathrm{a}$ & $1,54 \mathrm{a}$ & $(-)$ \\
\hline \multirow{4}{*}{$50 \mathrm{HST}$} & $15 \mathrm{tha}^{-1}$ & $1,56 \mathrm{a}$ & $1,53 \mathrm{a}$ & $1,56 \mathrm{a}$ & $1,55 \mathrm{a}$ \\
\hline & $25 \mathrm{tha}^{-1}$ & $1,53 \mathrm{a}$ & $1,54 \mathrm{a}$ & $1,52 \mathrm{a}$ & $1,53 \mathrm{a}$ \\
\hline & $35 \mathrm{tha}^{-1}$ & $1,58 \mathrm{a}$ & $1,58 \mathrm{a}$ & $1,58 \mathrm{a}$ & $1,58 \mathrm{a}$ \\
\hline & Rerata & $1,56 \mathrm{a}$ & $1,55 \mathrm{a}$ & $1,55 \mathrm{a}$ & $(-)$ \\
\hline \multirow{4}{*}{75 HST } & $15 \mathrm{t} \mathrm{ha}^{-1}$ & $1,51 \mathrm{a}$ & $1,49 \mathrm{a}$ & $1,49 \mathrm{a}$ & $1,50 \mathrm{a}$ \\
\hline & $25 \mathrm{tha}^{-1}$ & $1,50 \mathrm{a}$ & $1,49 \mathrm{a}$ & $1,52 \mathrm{a}$ & $1,50 \mathrm{a}$ \\
\hline & $35 \mathrm{tha}^{-1}$ & $1,53 \mathrm{a}$ & $1,53 \mathrm{a}$ & $1,51 \mathrm{a}$ & $1,52 \mathrm{a}$ \\
\hline & Rerata & $1,51 \mathrm{a}$ & $1,50 \mathrm{a}$ & $1,51 \mathrm{a}$ & $(-)$ \\
\hline
\end{tabular}

Keterangan: Angka pada baris dan kolom yang diikuti dengan huruf yang sama tidak berbeda nyata menurut uji DMRT @ 5\%. ( - ) : Tidak terjadi interaksi antar faktor

\subsection{Tinggi Tanaman}

Tanaman terus bertambah tinggi selama penelitian. Hasil sidik ragam (Anova) menunjukkan tidak terjadi interaksi antara perlakuan takaran pupuk kandang babi dan jarak tanam pada setiap waktu pengamatan. Takaran pupuk kandang babi maupun jarak tanam juga tidak memberikan pengaruh utama yang nyata terhadap berat volume tanah setiap waktu pengamatan.

Pada waktu pengamatan 25 HST dan 50 HST, tanaman yang diberikan pupuk kandang babi dengan takaran $35 \mathrm{t} \mathrm{ha}^{-1}$ cenderung lebih tinggi dan yang pendek adalah tanaman yang diberikan pupuk kandang babi dengan takaran $15 \mathrm{t}$ $\mathrm{ha}^{-1}$. Namun, pada pengamatan terakhir tanaman yang diberikan pupuk kandang babi dengan takaran $25 \mathrm{t} \mathrm{ha}^{-1}$ cenderung lebih tinggi dan yang terpendek adalah tanaman yang diberikan pupuk kandang babi dengan takaran $15 \mathrm{t} \mathrm{ha}^{-1}$. Saat pengamatan 25 HST wortel yang ditanam dengan jarak tanam $15 \mathrm{~cm}$ x $15 \mathrm{~cm}$ cenderung lebih tinggi sedangkan pada pengamatan selanjutnya, wortel yang ditanam dengan jarak tanam $10 \mathrm{~cm}$ x $20 \mathrm{~cm}$ cenderung lebih tinggi.

\begin{tabular}{|c|c|c|c|c|c|}
\hline \multirow{2}{*}{$\begin{array}{c}\text { Waktu } \\
\text { Pengamatan }\end{array}$} & \multirow{2}{*}{$\begin{array}{c}\text { Takaran } \\
\text { Pupuk }\end{array}$} & \multicolumn{3}{|c|}{ Jarak Tanam } & \multirow{2}{*}{ Rerata } \\
\hline & & $10 \times 15$ & $10 \times 20$ & $15 \times 15$ & \\
\hline \multirow{4}{*}{25 HST } & $15 \mathrm{tha}^{-1}$ & $5,1 \mathrm{a}$ & $5,5 \mathrm{a}$ & $5,4 \mathrm{a}$ & $5,3 \mathrm{a}$ \\
\hline & $25 \mathrm{tha}^{-1}$ & $5,8 \mathrm{a}$ & $5,2 \mathrm{a}$ & $5,8 \mathrm{a}$ & $5,6 \mathrm{a}$ \\
\hline & $35 \mathrm{t} \mathrm{ha}^{-1}$ & $5,6 \mathrm{a}$ & $5,8 \mathrm{a}$ & $5,7 \mathrm{a}$ & $5,7 \mathrm{a}$ \\
\hline & Rerata & $5,5 \mathrm{a}$ & $5,5 \mathrm{a}$ & $5,6 \mathrm{a}$ & $(-)$ \\
\hline \multirow{4}{*}{$50 \mathrm{HST}$} & $15 \mathrm{t} \mathrm{ha}^{-1}$ & $23,4 \mathrm{a}$ & $24,3 \mathrm{a}$ & $25,3 \mathrm{a}$ & $24,3 \mathrm{a}$ \\
\hline & $25 \mathrm{t} \mathrm{ha}^{-1}$ & $25,7 \mathrm{a}$ & $25,3 \mathrm{a}$ & $23,1 \mathrm{a}$ & $24,7 \mathrm{a}$ \\
\hline & $35 \mathrm{t} \mathrm{ha}^{-1}$ & $24,7 \mathrm{a}$ & $27,0 \mathrm{a}$ & $25,3 \mathrm{a}$ & $25,6 \mathrm{a}$ \\
\hline & Rerata & $24,6 \mathrm{a}$ & $25,5 \mathrm{a}$ & $24,6 \mathrm{a}$ & $(-)$ \\
\hline \multirow{4}{*}{75 HST } & $15 \mathrm{t} \mathrm{ha}^{-1}$ & $40,1 \mathrm{a}$ & $40,7 \mathrm{a}$ & $41,1 \mathrm{a}$ & $40,7 \mathrm{a}$ \\
\hline & $25 \mathrm{t} \mathrm{ha}^{-1}$ & $43,6 \mathrm{a}$ & $39,6 \mathrm{a}$ & $42,7 \mathrm{a}$ & $41,9 \mathrm{a}$ \\
\hline & $35 \mathrm{t} \mathrm{ha}^{-1}$ & $39,7 \mathrm{a}$ & $44,3 \mathrm{a}$ & $39,9 \mathrm{a}$ & $41,3 \mathrm{a}$ \\
\hline & Rerata & $41,1 \mathrm{a}$ & $41,5 \mathrm{a}$ & $41,2 \mathrm{a}$ & $(-)$ \\
\hline
\end{tabular}

Keterangan: $\quad$ Angka pada baris dan kolom yang diikuti dengan huruf yang sama tidak berbeda nyata menurut uji DMRT @ 5\%. ( - ) : Tidak terjadi interaksi antar faktor

3.5 Luas Daun

Hasil sidik ragam (Anova) menunjukkan tidak terjadi interaksi antara takaran pupuk kandang babi dan jarak tanam terhadap luas daun.

Tabel 6. Luas Daun $\left(\mathrm{cm}^{2}\right)$

\begin{tabular}{clllr}
\hline Takaran & \multicolumn{3}{c}{ Jarak Tanam } & \multirow{2}{*}{ Rerata } \\
\cline { 2 - 4 } Pupuk & $10 \times 15$ & $10 \times 20$ & $15 \times 15$ & \\
\hline $15 \mathrm{t} \mathrm{ha}^{-1}$ & $669,85 \mathrm{ab}$ & $742,64 \mathrm{ab}$ & $606,75 \mathrm{ab}$ & $673,08 \mathrm{a}$ \\
$25 \mathrm{t} \mathrm{ha}^{-1}$ & $862,86 \mathrm{ab}$ & $386,17 \mathrm{~b}$ & $1876,46 \mathrm{a}$ & $1041,83 \mathrm{a}$ \\
$35 \mathrm{t} \mathrm{ha}^{-1}$ & $621,38 \mathrm{ab}$ & $559,14 \mathrm{ab}$ & $657,25 \mathrm{ab}$ & $612,59 \mathrm{a}$ \\
\hline Rerata & $718,03 \mathrm{a}$ & $562,65 \mathrm{a}$ & $1046,82 \mathrm{a}$ & $(-)$ \\
\hline Keterangan : & $\begin{array}{l}\text { Angka pada baris dan kolom yang diikuti dengan huruf yang sama } \\
\end{array}$ & $\begin{array}{l}\text { tidak berbeda nyata menurut uji DMRT @ 5\%. ( - ) : Tidak terjadi } \\
\text { interaksi antar faktor }\end{array}$ &
\end{tabular}

Takaran pupuk kandang babi maupun jarak tanam juga tidak memberikan pengaruh utama yang nyata terhadap luas daun tetapi data pada Tabel 6 . menunjukkan bahwa permukaan daun tanaman wortel yang diberikan pupuk kandang babi dengan takaran $25 \mathrm{t} \mathrm{ha}^{-1}$ cenderung lebih luas sedangkan permukaan daun tanaman wortel yang diberikan pupuk kandang babi dengan takaran $35 \mathrm{t} \mathrm{ha}^{-1}$ paling sempit. Permukaan daun tanaman wortel yang ditanam dengan jarak tanam $15 \mathrm{~cm}$ x $15 \mathrm{~cm}$ cenderung lebih luas sedangkan tanaman wortel yang ditanam dengan jarak tanam $10 \mathrm{~cm}$ x $20 \mathrm{~cm}$ paling sempit.

\subsection{Panjang Umbi}

Hasil sidik ragam (Anova) menunjukkan bahwa tidak terjadi interaksi antara takaran pupuk kandang babi dan jarak tanam terhadap terhadap panjang umbi.

Tabel 7. Panjang Umbi (cm)

\begin{tabular}{cllll}
\hline Takaran & \multicolumn{3}{c}{ Jarak Tanam } & \multirow{2}{*}{ Rerata } \\
\cline { 2 - 4 } Pupuk & $10 \times 15$ & $10 \times 20$ & $15 \times 15$ & \\
\hline $15 \mathrm{t} \mathrm{ha}^{-1}$ & $20,2 \mathrm{ab}$ & $19,2 \mathrm{ab}$ & $22,0 \mathrm{a}$ & $20,5 \mathrm{a}$ \\
$25 \mathrm{t} \mathrm{ha}^{-1}$ & $18,6 \mathrm{ab}$ & $19,7 \mathrm{ab}$ & $19,2 \mathrm{ab}$ & $19,2 \mathrm{ab}$ \\
$35 \mathrm{t} \mathrm{ha}^{-1}$ & $18,0 \mathrm{~b}$ & $18,5 \mathrm{ab}$ & $18,6 \mathrm{ab}$ & $18,3 \mathrm{~b}$ \\
\hline Rerata & $18,9 \mathrm{a}$ & $19,1 \mathrm{a}$ & $19,9 \mathrm{a}$ & $(-)$
\end{tabular}

Keterangan: Angka pada baris dan kolom yang diikuti dengan huruf yang sama tidak berbeda nyata menurut uji DMRT @ 5\%. ( - ) : Tidak terjadi interaksi antar faktor

Perlakuan takaran pupuk kandang babi berpengaruh secara nyata terhadap panjang umbi dimana pemberian pupuk kandang babi dengan takaran $15 \mathrm{t} \mathrm{ha}^{-1}$ menghasilkan umbi yang paling panjang dan berbeda nyata dengan panjang umbi wortel yang diberikan pupuk kandang babi dengan takaran $35 \mathrm{t} \mathrm{ha}^{-1}$ tetapi tidak berbeda nyata dengan panjang umbi wortel yang diberikan pupuk kandang babi dengan takaran $25 \mathrm{t} \mathrm{ha}^{-1}$. Jarak tanam tidak berpengaruh secara nyata terhadap panjang umbi tetapi data Tabel 7 . menunjukkan bahwa umbi wortel yang ditanam dengan jarak tanam $15 \mathrm{~cm}$ x $15 \mathrm{~cm}$ cenderung lebih panjang sedangkan umbi wortel yang ditanam dengan jarak tanam $10 \mathrm{~cm}$ x 15 $\mathrm{cm}$ paling pendek.

\subsection{Diameter Umbi}

Hasil sidik ragam (Anova) menunjukkan bahwa tidak terjadi interaksi antara takaran pupuk kandang babi dan jarak tanam terhadap diameter umbi.

Takaran pupuk kandang babi maupun jarak tanam juga tidak memberikan pengaruh utama yang nyata terhadap diameter umbi tetapi data pada Tabel 8 . menunjukkan bahwa diameter umbi wortel yang diberikan pupuk kandang babi dengan takaran $15 \mathrm{t} \mathrm{ha}^{-1}$ cenderung lebih besar sedangkan umbi wortel yang 
diberikan pupuk kandang babi dengan takaran $25 \mathrm{t} \mathrm{ha}^{-1}$ paling kecil. Diameter umbi wortel yang ditanam dengan jarak tanam $10 \mathrm{~cm} \times 20 \mathrm{~cm}$ cenderung lebih besar sedangkan umbi wortel yang ditanam dengan jarak tanam $10 \mathrm{~cm}$ x $15 \mathrm{~cm}$ paling kecil.

Tabel 8. Diameter Umbi (mm)

\begin{tabular}{ccccc}
\hline Takaran & \multicolumn{3}{c}{ Jarak Tanam } & \multirow{2}{*}{ Rerata } \\
\cline { 2 - 4 } Pupuk & $10 \times 15$ & $10 \times 20$ & $15 \times 15$ & \\
\hline $15 \mathrm{t} \mathrm{ha}^{-1}$ & $41,3 \mathrm{a}$ & $57,9 \mathrm{a}$ & $42,8 \mathrm{a}$ & $47,3 \mathrm{a}$ \\
$25 \mathrm{t} \mathrm{ha}^{-1}$ & $38,4 \mathrm{a}$ & $41,4 \mathrm{a}$ & $42,3 \mathrm{a}$ & $40,7 \mathrm{a}$ \\
$35 \mathrm{t} \mathrm{ha}^{-1}$ & $38,1 \mathrm{a}$ & $43,7 \mathrm{a}$ & $44,1 \mathrm{a}$ & $42,0 \mathrm{a}$ \\
\hline Rerata & $39,3 \mathrm{a}$ & $47,7 \mathrm{a}$ & $43,1 \mathrm{a}$ & $(-)$ \\
\hline Keterangan : & Angka pada baris dan kolom yang diikuti dengan huruf & yang sama
\end{tabular}
tidak berbeda nyata menurut uji DMRT @ 5\%. (-):Tidak terjad interaksi antar faktor

\subsection{Berat Umbi Per Tanaman}

Hasil sidik ragam (Anova) menunjukkan bahwa tidak terjadi interaksi antara takaran pupuk kandang babi dan jarak tanam terhadap berat umbi per tanaman. Takaran pupuk kandang babi maupun jarak tanam juga tidak memberikan pengaruh utama yang nyata terhadap berat umbi per tanaman tetapi data pada Tabel 9. menunjukkan bahwa umbi setiap tanaman yang diberikan pupuk kandang babi dengan takaran $15 \mathrm{t} \mathrm{ha}^{-1}$ cenderung lebih berat sedangkan umbi setiap tanaman yang diberikan pupuk kandang babi dengan takaran $35 \mathrm{t} \mathrm{ha}^{-1}$ paling ringan. Umbi setiap tanaman yang ditanam dengan jarak tanam $15 \mathrm{~cm} \times 15 \mathrm{~cm}$ cenderung lebih berat sedangkan umbi wortel yang ditanam dengan jarak tanam $10 \mathrm{~cm}$ x $15 \mathrm{~cm}$ paling ringan.

Tabel 9. Berat Umbi Per Tanaman (g)

\begin{tabular}{cllll}
\hline Takaran & \multicolumn{3}{c}{ Jarak Tanam } & \multirow{2}{*}{ Rerata } \\
\cline { 2 - 4 } Pupuk & \multicolumn{1}{c}{$10 \times 15$} & $10 \times 20$ & $15 \times 15$ & \\
\hline $15 \mathrm{t} \mathrm{ha}^{-1}$ & $113,4 \mathrm{ab}$ & $120,2 \mathrm{ab}$ & $131,7 \mathrm{a}$ & $121,8 \mathrm{a}$ \\
$25 \mathrm{t} \mathrm{ha}^{-1}$ & $118,5 \mathrm{ab}$ & $116,8 \mathrm{ab}$ & $114,9 \mathrm{ab}$ & $116,7 \mathrm{a}$ \\
$35 \mathrm{t} \mathrm{ha}^{-1}$ & $102,6 \mathrm{~b}$ & $118,3 \mathrm{ab}$ & $122,8 \mathrm{ab}$ & $114,6 \mathrm{a}$ \\
\hline Rerata & $111,5 \mathrm{a}$ & $118,4 \mathrm{a}$ & $123,1 \mathrm{a}$ & $(-)$ \\
\hline Keterangan : & Angka pada baris dan kolom yang diikuti dengan huruf yang sama \\
& tidak berbeda nyata menurut uji DMRT @ 5\%. ( - ) : Tidak terjadi \\
& interaksi antar faktor
\end{tabular}

\subsection{Berat Umbi Per Petak}

Hasil sidik ragam (Anova) menunjukkan bahwa tidak terjadi interaksi antara takaran pupuk kandang babi dan jarak tanam.

Takaran pupuk kandang babi maupun jarak tanam juga tidak memberikan pengaruh utama yang nyata terhadap berat umbi per petak tetapi data pada Tabel 10. menunjukkan bahwa umbi setiap petak dari tanaman yang diberikan pupuk kandang babi dengan takaran $35 \mathrm{t} \mathrm{ha}^{-1}$ cenderung lebih berat sedangkan umbi setiap petak dari tanaman yang diberikan pupuk kandang babi dengan takaran $15 \mathrm{t} \mathrm{ha}^{-1}$ paling ringan. Umbi setiap petak dari tanaman yang ditanam dengan jarak tanam $15 \mathrm{~cm}$ x $15 \mathrm{~cm}$ cenderung lebih berat sedangkan umbi setiap petak dari tanaman yang ditanam dengan jarak tanam $10 \mathrm{~cm} \times 15 \mathrm{~cm}$ paling ringan.

Tabel 10. Berat Umbi Per Petak $\left(\mathrm{t} \mathrm{ha}^{-1}\right)$

\begin{tabular}{cllll}
\hline Takaran & \multicolumn{3}{c}{ Jarak Tanam } & \multirow{2}{*}{ Rerata } \\
\cline { 2 - 4 } Pupuk & $10 \times 15$ & $10 \times 20$ & $15 \times 15$ & \\
\hline $15 \mathrm{t} \mathrm{ha}^{-1}$ & $22,768 \mathrm{a}$ & $25,298 \mathrm{a}$ & $29,464 \mathrm{a}$ & $25,843 \mathrm{a}$ \\
$25 \mathrm{t} \mathrm{ha}^{-1}$ & $29,167 \mathrm{a}$ & $25,595 \mathrm{a}$ & $27,976 \mathrm{a}$ & $27,579 \mathrm{a}$ \\
$35 \mathrm{t} \mathrm{ha}^{-1}$ & $30,060 \mathrm{a}$ & $27,679 \mathrm{a}$ & $35,119 \mathrm{a}$ & $30,952 \mathrm{a}$ \\
\hline Rerata & $27,331 \mathrm{a}$ & $26,190 \mathrm{a}$ & $30,853 \mathrm{a}$ & $(-)$
\end{tabular}

Keterangan: Angka pada baris dan kolom yang diikuti dengan huruf yang sama Angka pada baris dan kolom yang diikuti dengan huruf yang sama
tidak berbeda nyata menurut uji DMRT @ $5 \%$. ( - ) : Tidak terjadi interaksi antar faktor

\subsection{Berat Segar Berangkasan}

Hasil sidik ragam (Anova) menunjukkan bahwa tidak terjadi interaksi antara takaran pupuk kandang babi dan jarak tanam.

Tabel 11. Berat Segar Berangkasan $\left(\mathrm{t} \mathrm{ha}^{-1}\right)$

\begin{tabular}{clllc}
\hline Takaran & \multicolumn{3}{c}{ Jarak Tanam } & \multirow{2}{*}{ Rerata } \\
\cline { 2 - 4 } Pupuk & $10 \times 15$ & $10 \times 20$ & $15 \times 15$ & \\
\hline $15 \mathrm{t} \mathrm{ha}^{-1}$ & $18,006 \mathrm{a}$ & $11,905 \mathrm{a}$ & $12,500 \mathrm{a}$ & $14,137 \mathrm{a}$ \\
$25 \mathrm{t} \mathrm{ha}^{-1}$ & $16,369 \mathrm{a}$ & $12,500 \mathrm{a}$ & $16,369 \mathrm{a}$ & $15,079 \mathrm{a}$ \\
$35 \mathrm{t} \mathrm{ha}^{-1}$ & $13,244 \mathrm{a}$ & $13,393 \mathrm{a}$ & $12,946 \mathrm{a}$ & $13,194 \mathrm{a}$ \\
\hline Rerata & $15,873 \mathrm{a}$ & $12,599 \mathrm{a}$ & $13,938 \mathrm{a}$ & $(-)$ \\
\hline
\end{tabular}

Keterangan : $\quad$ Angka pada baris dan kolom yang diikuti dengan huruf yang sama tidak berbeda nyata menurut uji DMRT @ 5\%. ( - ) : Tidak terjadi interaksi antar faktor

Takaran pupuk kandang babi maupun jarak tanam juga tidak memberikan pengaruh utama yang nyata terhadap berat segar berangkasan tetapi data pada Tabel 11. menunjukkan bahwa berat segar berangkasan dari tanaman yang diberikan pupuk kandang babi dengan takaran $25 \mathrm{t} \mathrm{ha}^{-1}$ cenderung lebih berat sedangkan berangkasan segar dari tanaman yang diberikan pupuk kandang babi dengan takaran $35 \mathrm{t} \mathrm{ha}^{-1}$ paling ringan. Berangkasan segar dari tanaman yang ditanam dengan jarak tanam $10 \mathrm{~cm}$ x $15 \mathrm{~cm}$ cenderung lebih berat sedangkan berangkasan segar dari tanaman yang ditanam dengan jarak tanam $10 \mathrm{~cm}$ x 20 $\mathrm{cm}$ paling ringan.

\subsection{Berat Kering Berangkasan}

Hasil sidik ragam (Anova) menunjukkan tidak terjadi interaksi antara takaran pupuk kandang babi dan jarak tanam terhadap berat kering berangkasan

Takaran pupuk kandang babi maupun jarak tanam juga tidak memberikan pengaruh utama yang nyata terhadap berat kering berangkasan tetapi data pada Tabel 12. menunjukkan bahwa berat kering berangkasan dari tanaman yang diberikan pupuk kandang babi dengan takaran $15 \mathrm{t} \mathrm{ha}^{-1}$ cenderung lebih berat sedangkan berangkasan kering dari tanaman yang diberikan pupuk kandang babi dengan takaran $35 \mathrm{t} \mathrm{ha}^{-1}$ paling ringan. Berangkasan kering dari tanaman yang ditanam dengan jarak tanam $15 \mathrm{~cm}$ x $15 \mathrm{~cm}$ cenderung lebih berat sedangkan berangkasan kering dari tanaman yang ditanam dengan jarak tanam $10 \mathrm{~cm} \times 20 \mathrm{~cm}$ paling ringan.

Tabel 12. Berat Kering Berangkasan ( $\left.\mathrm{t} \mathrm{ha}^{-1}\right)$

\begin{tabular}{cllll}
\hline Takaran & \multicolumn{3}{c}{ Jarak Tanam } & \multirow{2}{*}{ Rerata } \\
\cline { 2 - 4 } Pupuk & $10 \times 15$ & $10 \times 20$ & $15 \times 15$ & \\
\hline $15 \mathrm{t} \mathrm{ha}^{-1}$ & $2,103 \mathrm{ab}$ & $2,314 \mathrm{ab}$ & $2,449 \mathrm{a}$ & $2,288 \mathrm{a}$ \\
$25 \mathrm{t} \mathrm{ha}^{-1}$ & $2,132 \mathrm{ab}$ & $2,210 \mathrm{ab}$ & $2,099 \mathrm{ab}$ & $2,147 \mathrm{a}$ \\
$35 \mathrm{t} \mathrm{ha}^{-1}$ & $2,194 \mathrm{ab}$ & $1,677 \mathrm{~b}$ & $2,293 \mathrm{ab}$ & $2,055 \mathrm{a}$ \\
\hline Rerata & $2,143 \mathrm{a}$ & $2,067 \mathrm{a}$ & $2,280 \mathrm{a}$ & $(-)$ \\
\hline Keterangan : & $\begin{array}{l}\text { Angka pada baris dan kolom yang diikuti dengan huruf yang sama } \\
\end{array}$ & tidak berbeda nyata menurut uji DMRT @ 5\%. ( - ) : Tidak terjadi \\
& interaksi antar faktor
\end{tabular}

\subsection{Indeks Panen}

Hasil sidik ragam (Anova) menunjukkan tidak terjadi pengaruh interaksi antara takaran pupuk kandang babi dan jarak tanam terhadap indeks panen. Takaran pupuk kandang babi maupun jarak tanam juga tidak memberikan pengaruh utama yang nyata terhadap indeks panen tetapi data pada Tabel 13 menunjukkan bahwa indeks panen dari tanaman yang diberikan pupuk kandang babi dengan takaran $35 \mathrm{t} \mathrm{ha}^{-1}$ cenderung lebih tinggi sedangkan indeks panen dari tanaman yang diberikan pupuk kandang babi dengan takaran $25 \mathrm{t}^{-\mathrm{ha}^{-1}}$ paling rendah. Indeks panen dari tanaman yang ditanam dengan jarak tanam 15 $\mathrm{cm}$ x $15 \mathrm{~cm}$ cenderung lebih tinggi sedangkan indeks panen dari tanaman yang ditanam dengan jarak tanam $10 \mathrm{~cm}$ x $15 \mathrm{~cm}$ paling rendah.

Tabel 13. Indeks Panen (\%)

\begin{tabular}{cllll}
\hline Takaran & \multicolumn{3}{c}{ Jarak Tanam } & \multirow{2}{*}{ Rerata } \\
\cline { 2 - 4 } Pupuk & $10 \times 15$ & \multicolumn{1}{c}{$10 \times 20$} & $15 \times 15$ & \\
\hline $15 \mathrm{t} \mathrm{ha}^{-1}$ & $59,4 \mathrm{ab}$ & $68,2 \mathrm{ab}$ & $70,4 \mathrm{a}$ & $66,0 \mathrm{a}$ \\
$25 \mathrm{t} \mathrm{ha}^{-1}$ & $65,6 \mathrm{ab}$ & $67,4 \mathrm{ab}$ & $64,4 \mathrm{ab}$ & $65,8 \mathrm{a}$ \\
$35 \mathrm{t} \mathrm{ha}^{-1}$ & $70,1 \mathrm{ab}$ & $67,8 \mathrm{~b}$ & $71,8 \mathrm{ab}$ & $69,9 \mathrm{a}$ \\
\hline Rerata & $65,0 \mathrm{a}$ & $67,8 \mathrm{a}$ & $68,9 \mathrm{a}$ & $(-)$ \\
\hline Keterangan : & Angka pada baris dan kolom yang diikuti dengan huruf yang sama \\
& tidak berbeda nyata menurut uji DMRT @ 5\%. ( - ) : Tidak terjadi \\
& interaksi antar faktor
\end{tabular}

\subsection{Pembahasan}

Hasil sidik ragam (Anova) menunjukkan tidak terjadi interaksi antara perlakuan takaran pupuk kandang babi dan jarak tanam pada semua parameter pengamatan. Pengaruh utama takaran pupuk kandang babi terhadap berat segar umbi per petak tidak berpengaruh nyata tetapi takaran $3535 \mathrm{t} \mathrm{ha}^{-1}$ memberikan hasil paling tinggi, hal ini didukung pula dengan indeks panen yang juga memberikan nilai tertinggi pada takaran yang sama. Dengan demikian takaran pupuk $35 \mathrm{t} \mathrm{ha}^{-1}$ dapat memberikan hasil yang terbaik bagi tanaman wortel, meskipun umbi segar per tanamannya memberikan berat paling ringan, permukaan daun yang lebih sempit, umbi yang lebih pendek, berangkasan segar dan berangkasan keringnya juga paling ringan. Hal ini menggambarkan bahwa berat segar umbi per petak lebih representatif dalam memberikan hasil tanaman wortel dan pemberian pupuk dengan takaran tersebut lebih dimanfaatkan bagi peningkatan hasil umbi wortel dari pada peningkatan komponen vegetatifnya.

Pengaruh utama jarak tanam terhadap berat segar umbi per petak juga tidak berpengaruh secara nyata, tetapi perlakuan jarak tanam $15 \mathrm{~cm} \mathrm{x} 15 \mathrm{~cm}$ menghasilkan umbi segar per petaknya paling berat. Hal ini didukung juga oleh permukan daun yang lebih luas, umbi yang lebih panjang, umbi segar per tanaman yang lebih berat, berangkasan kering yang lebih berat serat indeks panen yang lebih tinggi, meskipun memiliki tanaman yang tidak terlalu tinggi, diameter umbi yang tidak terlalu besar serta berangkasan segar yang tidak terlalu berat. Ini membuktikan bahwa pemberian jarak tanam $15 \mathrm{~cm} \times 15 \mathrm{~cm}$ pada tanaman wortel memberikan pertumbuhan dan hasil yang lebih baik.

\section{Simpulan}

Berdasarkan hasil penelitian dan pembahasan dapat disimpulkan beberapa hal sebagai berikut :

a. Tidak terjadi pengaruh interaksi antara takaran pupuk kandang babi dan jarak tanam terhadap semua parameter.

b. Takaran pupuk kandang babi hanya berpengaruh nyata pada kadar lengas tanah 50 HST dan panjang umbi sedangkan jarak tanam yang digunakan 
tidak berpengaruh pada parameter lingkungan maupun pertumbuhan dan hasil tanaman wortel.

c. Pemberian pupuk kandang babi dengan takaran $35 \mathrm{t} \mathrm{ha}^{-1}$ memberikan hasil tertinggi yakni $30,95 \mathrm{t} \mathrm{ha}^{-1}$, sedangkan jarak tanam $15 \mathrm{~cm} \times 15 \mathrm{~cm}$ memberikan hasil wortel tertinggi yakni $30,85 \mathrm{t} \mathrm{ha}^{-1}$.

\section{Pustaka}

Badan Pusat Statistik TTU. 2007. Timor Tengah Utara Dalam Angka. BPS TTU. Kefamenanu.

Badan Pusat Statistik NTT. 2014. Nusa Tenggara Timur Dalam Angka. BPS NTT. Kupang.

Cahyono, B. 2002. Wortel. Kanisius. Yogyakarta.

Direktorat Jenderal Hortikultura. 2012. Pusat Data dan Informasi Pertanian. Buletin Konsumsi Pangan. 4 (4): 29-34.

Gomez K A dan Gomez A A. 1995. Prosedur Statistik untuk Penelitian Pertanian. Edisi ke 2. UI Press. Jakarta.

Hadirochmat. 2006. Pertumbuhan dan Hasil Benih Wortel. Dosen Faperta Universitas Winaya Mukti.

Hardjowigeno. 2002. Ilmu Tanah Akademik Persind. Jakarta.

Indrayanti A L. 2010. Pengaruh Jarak Tanam dan Jumlah Benih Terhadap Pertumbuhan Vegetatif Jagung Muda. J. Media SainS. 2(2):153-196.

Nurhayati, D. 2000. Pengaruh Berbagai Dosis Pupup Kandang Ayam dan Konsentrasi Ammonium Molybdat Terhadap Pertumbuha dan Hasil Tanaman Kacang Panjang. [Skripsi] Fakultas Pertanian Universitas Brawijaya. Malang.

Santoso. 1994. Kecap dan Tauco Kedela. Kanisius. Yogyakarta.

Setiawan. 2012. Pengaruh Cekaman Kurang Air Terhadap Beberapa Karakter Fisiologi Tanaman Nilai (Pogostemon Cablin Benth). [Skripsi] Fakultas Pertanian UGM Kujas Bulak Sumor Yogyakarta. 